\title{
Possibilities for ecological production of new wear resistant Fe-C based alloys
}

\begin{abstract}
We present in general framework a part of by now obtained results of the authors studies in the period 1968-2003 about possibilities for obtaining new high-alloyed and wear-resistant founded alloys on Fe-C basis grey cast iron and complex alloyed steels and cast iron of different systems with different structure, reflected inover 130 publications, innovations, patents and other scientific studies. The results of the studies make possible to determine not only the directions for application of the obtained alloys in practices, but also to outline ecological and technical directions for obtaining of new high strength and wear-resistant alloys with $\mathrm{N}$, using the possibilities of the new gas metallurgy with gaseous and volatile elements under pressure.
\end{abstract}

Keywords: new cast alloys, grey cast iron, complex alloyed steels and cast iron alloying with $N$, mechanic characteristics, ecology, application, perspectives, prognostication.

\section{INTRODUCTION}

The intensive progress of world science imposes the necessity to create new materials and alloys with high physico-mechanical and exploitation characterristics with simultaneous decrease in material energy and other expenses for achieving high quality. Development of machine building as a strategic sector is inevitably connected to the creation of ever newer and more effective technologic and ecological processes in foundry. At the end of the 20 and on the beginning of 21 century tradition metallurgic and founding technologies are exhausted in their possibilities to solve these complex issues. From the three thermodynamic factors (composition, temperature and pressure), characterising and defining processes and phenomena in substances (the Nature), resp.structure and properties of materials (alloys) in classic technologies are practically used only the first two. If studying and applying of the possibilities of vacuum technologies are developed well enough vacuum technologies are developed well enough, then the study and application of the possibilities of pressure, still at an initial stage seems to be very perspective, having in mind the challenges of the $21{ }^{\text {st }}$ century [1-4].

Bulgarian methods with gas counter pressure (MOMGP) presents a fundamental innovation for great potential possibilities to develop and solve actual-priority Global problems of Mankind; creation of technologic and ecological as well as economically profitable machines and devices, new materials (alloys) and their products [1-4]. One of the most perspective directions of MOMGP is creation of new machine-building materials(steels and cast iron), alloyed with gaseous elements [1,5-8].

Author's address: Bulgarian Chemical Communications Instutute of Chemical Engineering Bulgarian Academy of Sciences, Sofia, Bulgaria

Received for Publication: 08. 01. 2014.

Accepted for Publication: 26. 03. 2014.
Of all known methods for improvement of structure and properties of the alloys on ferro-basis the most effective is alloying. MOMGP outlined the principal fundamental possibilities and directions for development of the new gaseous metallurgy with volatile elements and substances. Nitrogen as the most common in Nature gas and residual product of a number of industrial production, processing the unique property to substitute expensive and deficit elements like: $\mathrm{Ni}, \mathrm{Cu}, \mathrm{Co},(\mathrm{Mn}, \mathrm{Zn})$ etc. and to improve some physic-mechanic and exploitation characteristics in times, not in percentage, completely corresponds to some of the challenges and the outlined Global problems of Mankind for the present and future [1-4].

Yet for unknown reasons the efforts of scientist are directed towards studying of possibilities to create most of all non-corrodible deformable steels. For cast alloys many restrictions in alloying with $\mathrm{C}$ and $\mathrm{N}$ come down as well as for other carbon-nitride forming elements, which imposes requirements for enough and high technological plasticity of deformable steels, treattability with cutting instruments, corrosion resistance etc. This shows that possibilities for obtaining of new $\mathrm{N}$-containing alloys aimed at casts are many times bigger [7-12, 1529]. With the increase of productivity of machines the wearing of details through friction increases. This leads to increase of capital investments for amortisation and for producing spare parts.

The needs for wear-resistant materials for details in conditions of abrasive, hidroabrasive, strike abrasive and other types wearing are constantly growing in world range. This is due to constant decrease in ores, resp. raw materials traditionally used for obtaining of high-quality products, for enhancing all activities linked to treatment and processing of Earth crust and bowels as well as the constant development of mechanisation in industry agriculture and transport. The building of ever more 
power full and automatic new machines and devices for digging making smaller, grinding mixing enriching, separating transport etc. requires and justifies the use of ever more qualitative and reliable and with longer life materials in order to minimize the defection and amortisation of spare parts.Ecologic problems are also topical [1 - 4]

In the institute of Metal Science - Bulgarian Academy of Scienses are carried out profound studies not only on possibilities for obtaining new $\mathrm{N}$ alloyed deformable steels, but new cat steels and cast irons as well.

\section{SUMMARISED RESULTS AND DISCUSSION}

\section{Possibilities for obtaining new $N$-containing high- strength and wear resistant ordinary grey pre- eutectic cast iron}

1.1 Of cast alloys used in modern machine building dominating position have grey cast iron microalling with $\mathrm{N}$ is possible trough introduction of gaseous as well as solid N-carriers [7, 9]

The treatment of melts of grey cast iron with $0,8-0,9$ grade of eutectics with $\mathrm{N}$ through $\mathrm{N}$-treated FeMn, without introduction of other elements is possible in founding under pressure (MOMGP), as well as in atmospheric conditions [1-4, 10, 11]. Thus both of the two absorbed elements $(\mathrm{Mn}, \mathrm{N})$ act stabilizingly for increase of $\mathrm{N}$-content, since the treatabiliry with cutting instruments sharply deteriorates. To prevent whitening is necessary quantity of the introduced $\mathrm{N}$-treated FeMn to be restricted (to $0,5-1 \%$ towards weight of treated metal). To prevent stabilising influence of $\mathrm{Mn}$ is needed additional metallurgical treatment with FeB. Introduction of $\mathrm{B}$ and $\mathrm{N}$ in stoichometric quantities securing formation of nitrides of $B$ (BN with crystal lattice wear to that of graphite being conductive to crystallisation and graphitization processes without thermal treatment, sharply decreases the affinity towards whitening and allows obtaining of grey cast iron, with increased $\mathrm{Mn}$ and $\mathrm{N}$ content [10-11]. Summarised $\mathrm{Mn}$ and $\mathrm{N}$ content of autors Bulgarian patent Claim RB23345 [8]:

Treatment of melts of grey cast iron with exit composition; $\mathrm{C}=2,0-3,4 \% ; \mathrm{Si}=1,7-2,2 \% ; \mathrm{Mn}=0,4-$ $0,5 \%$; S up to $0,04 \%, \mathrm{P}$ up to $0,08 \%, \mathrm{~N}$ up to $0,005-0,007 \%$ through $\mathrm{N}$-treated FeMn (containing influence of absorbed $\mathrm{Mn}$ and $\mathrm{N}$ leads to whitening (sample rain $050 \mathrm{~mm}$ ): a)after treatment under pressure $\left(6 / 18.10^{5} \mathrm{~Pa}\right.$; 6-pressure when introducing $\mathrm{N}$-carrier, 18-pressure of melt crystallisation $[7,12,15,22]$. Whitening starts at lower $\mathrm{Mn}$ content above 1,1-1,3\%) and lower content (above 0,010-0,0160\%).

1.2. On statistical basis are worked out mathematics models which help determine the influence of quantity of introduced $\mathrm{N}$-treated FeMn ,,q", resp of the absorbed $M n\left(\mathrm{C}_{\mathrm{Mn}}\right)$ after treating under pressure $6 / ! 8.105 \mathrm{~Pa}$; a) on quantity of absorbed $\mathrm{N}\left(\mathrm{C}_{\mathrm{N}}\right)$; $\left.\lg 58,8 \mathrm{C}_{\mathrm{N}}=0,14 \mathrm{C}_{\mathrm{Mn}} ; \mathrm{b}\right)$ on the extent of $N$ absorption $\left.\left(\eta_{N}\right) ; r\right]_{N}=20,4+14,578 q-$ $4,456 q^{2}$

1.3. We obtained grey cast iron containing high content of $\mathrm{Mn}$ and $\mathrm{N}$, thanks to the modifying and graphitizing influence of the products of "N-B" interaction; without applying long-iasting and expensive thermal treatment;

a) in founding under pressure $6 / 18.10^{5} \mathrm{~Pa}$-up to $2,5-3 \% \mathrm{Mn}$ and $0,05 \% \mathrm{~N}$; b) in founding in atmospheric conditions-up to $1,5-2 \% \mathrm{Mn}$ and up to $0,025 \% \mathrm{~N}$

1.4. The effect of the action of the products from the "N-B" interaction is bigger when the quantity of introduced $\mathrm{N}$ and $\mathrm{B}$ is bigger. It is visible even at low content; of $\mathrm{N}$ below $0,04-0,06 \%$ of B-below $0,1-0,15 \%$. The optimum quantity $\mathrm{FeB}$ (containing $20-22 \% \mathrm{~B}$ ) depends on $\mathrm{Mn}$ and $\mathrm{N}$ content and is within the range-0,025-1,5\% towards metal weight; a) in founding under pressure $6 / 18.10^{5} \mathrm{~Pa}-0,5-1,5 \%$; b)in founding in atmospheric conditions- $0.25-1 \%$.

1.5. To decrease the losses of $\mathrm{N}$ ( $\mathrm{N}$-carrier) is possible a change of part of the $\mathrm{N}$-treated FeMn with ordinary, without particular deterioration mechanic characteristics; a) in founding under pressure $6 / 18.10^{5} \mathrm{~Pa}$ up to $25-30 \%$; b) in founding in atmospheric conditions-up to $50 \%$.

1.6. On statistic basis are developed mathematics models which can help evaluate the influence of absorbed $\mathrm{Mn}$ (resp. accordings to conclusion $2, \mathrm{~N}$ ) on mechanic characteristics of cast iron, contain $55.10^{, 3}-150.10^{3} \% \mathrm{~B}$, after treatment under pressure $6 / 18.10^{5} \mathrm{~Pa}$; b) for strength tensile; $\sigma_{\mathrm{B}}=18,3+10,6 \mathrm{C}_{\mathrm{Mn}}$; b) strength of bending; $\sigma_{\mathrm{Bcndmg}}=$ $\left.38,58+20,260 C_{M n} ; C\right)$ for hardness, $H B=204,86+$ 23,025. $\mathrm{C}_{\mathrm{Mn}}$.

1.7. The obtained grey pre-eutectic after treatment as melt with $\mathrm{N}$-treated FeMn and FeB under pressure in atmospheric conditions have small grain and fine grain structure density and high mechanic properties and very good wear-resistance with satisfactory treatabiliry with cutting instruments [7, $8,10,11]$. Influence of $B$ is basically concluded in decreasing the cimentite quantity. $\mathrm{N}$-treating of melt underpressure 6/18. $10^{3} \mathrm{~Pa}$ in $\mathrm{N}$ medium increases the strength of tensile with $17-25 \%$ in comparison with analogous treatment in atmospheric conditions and more than 2 times towards exit non-treated cast iron. Wear resistance of obtained under pressure $6 / 18.10^{5}$ ) grey N-treated cast iron with higher $\mathrm{Mn}$ content is with $15-35 \%$ better than that of analogous treated cast iron in atmospheric conditions and depends on $\mathrm{Mn}$ content of $\mathrm{Mn}$ and satisfactory treteabality with 
cutting instruments which have comparable and better strength characteristics than the renound." Mihanite" cast iron and with many times better wear resistancre than it, consisting in; a)in founding in atmospheric conditions-up to $1,5-1,8 \% \mathrm{Mn}$ and 210-250HB. Experimentally it was determined that in atmospheric conditions to decrease the whitening in a sample body with $3-5 \mathrm{~mm}$ it is necessary to introduce $0,2-0,4 \% \mathrm{FeSi}-75$. Observations show that introduction of $0,018-0,025 \% \mathrm{~N}$ and up to $0,01 \% \mathrm{~B}$ is equivalent of modification with 0,6 $0,8 \% \mathrm{FeSi}-75$.wear resistance of $\mathrm{N}$-treated grey cast iron under equal other conditions is with 30 5)\% better than the modified with FeSi.

As a cryterion for research of wear resistance we used the loss in the weight of tested bodies of $\mathrm{N}$-treated grey cast iron under friction with lubrication. To this end we used laboratory mashine "Amsler". The tested rolls have diameter $35 \mathrm{~mm}$ and are $40 \mathrm{~mm}$ wide the sample is worked out of bearing steel and is quenched. The tested cast iron body is smashed to the samples with a force of 100 $\mathrm{kg}$. Stiding-15\%. The results of the carried industrial testing with grey cast iron from a special type show that the developed technology with patent RB23345 [8] can breach quality Grade 17 according to British standard BS1452, required in production of some details for engines with internal combustion and for some details for hydraulic machines [30]. These details are usually founded from the famous modified cast iron "Mihanaite'. The results from the laboratory and industrial observations show that the developed compositions of cast iron and technologies for casts from which is required high strength and wear resistance as well as to make cutting machines lighter metallurgic treatment can be carried out by existing conditions in founding factories in an ordinary founding bucket i.e no additional complex devices are needed. This makes technology easy to apply [30]. In point of view of technological utility and economic profit the future belongs to cast iron obtained in closed heat aggregates [412], By now obtained results show that a wide range of grey cast iron with high strength and wear resistance can be created. They contain $\mathrm{N}$ and are produced in atmospheric conditions as well as under higher pressure according to Bulgarian processes for gas counter pressure (MOMGP) [712, 30].

\section{Possibilities of formation of new austenite $N$ - containing high strength and wear resistant complex alloyed cast alloys of the systems $\mathrm{Fe}-\mathrm{Cr}-\mathrm{Mn}-\mathrm{C}-\mathrm{N}$ and Fe-Cr-Mn-C.}

Austenite is the most economic basis for creation of new alloys with special properties: wear resistance, heat resistance, corrosion resistance, non magnetism etc., combined with high mechanic characteristics and plasticity. Topical and very perspective is the problem about attempts to substitute for expensive and deficit austenite forming elements like: $\mathrm{Ni}, \mathrm{Cu}$, $\mathrm{Co}$ etc. with other cheaper ones $\mathrm{Mn}, \mathrm{N}, \mathrm{C}$. In other words, the systems $\mathrm{Fe}-\mathrm{Cr}-\mathrm{Mn}-\mathrm{C}-\mathrm{N}$ and Fe-Cr-Mn-C as a whole and as a basis for creating new alloys with special properties are not studied enough. Researches boil down to mainly attempts to substitute $\mathrm{Ni}$ with $\mathrm{Mn}$ or $\mathrm{Mn}$ with $\mathrm{N}$ in $\mathrm{C}$ content below $0,1-0,3 \%$ making possible a good plastic deformation. For more than 2-3 decades we studied those systems with a wice range of variation of basic components without additional alloying with other elements. As a result we obtained series of cast steels and cast iron with high mechanic properties and wear resistance in conditions of abrasive, hydro abrasive, strike abrasive wearing under cavitation and erosion. Some of them have good resistance towards oxidation at high temperature and good corrosion resistance, which make them applicable for short work at higher temperatures or in conditions of wearing and oxidation wearing in certain aggressive media etc. We studied possibilities to obtain new austenite complex alloyed cast alloys through treating the steel under pressure with MOMGP in order to obtain alloys with above equilibrium contents of $\mathrm{N}$ of the system $\mathrm{Fe}-\mathrm{Cr}-\mathrm{Mn}-\mathrm{C}-\mathrm{N}$ and atmospheric conditions: obtaining alloys with equilibrium contents $\mathrm{N}$ and $\mathrm{N}$-free alloys of the system Fe-Cr-MnC. Below we present results of some economic alloys.

2.1. Summarized results of studies on possibilities to obtain high strength austenite wear resistant alloys of the systems Fe-Cr-Mn-C-N and Fe$\mathrm{Cr}-\mathrm{Mn}-\mathrm{C}$ : The problem linked to obtaining of cast austenite alloys of the austenite class with high values of the yield strength $\left(\sigma_{02}\right)$ is wry topical. The values of $\sigma_{02}$ of classic austenite wear resistant) steels of Hatfield type (C110Mnl3) are low (to 35$40.10^{-7} \mathrm{~Pa}$ [13]. Values 02 in classic $\mathrm{Cr}-\mathrm{Ni}$ austenite steels of the type C10Crl8Ni9Ti are lower [14]. Under control regulation and observation of ratios between components forming solid solutions of substitution (most of all of $\mathrm{Cr}$ and $\mathrm{Mn}$ ) and of introduction ( $\mathrm{C}$ and $\mathrm{N}$ ) very good conditions of creation are created for effective action on structure. As a result we obtain high strong alloys with valuable properties. Improvement is in times not percentage. Stable austenite structure in $\mathrm{Ni}$-free alloys can be obtained only at certain ratios between basic components: $\mathrm{Cr}, \mathrm{Mn}, \mathrm{N}$ and $\mathrm{C}$. [7, $12,15-16,22]$. We studied cast austenite alloys in wide range of variation of the basic components; 
securing after high temperature austenitization $\left(1100-1200^{\circ} \mathrm{C}\right)$ austenite and austenite-carbide structure $[7,12,15] . \mathrm{C}=0,09-3,5 \%$, below $1 \% \mathrm{Si}$, to $10-30 \% \mathrm{Mn}$, to $3-14 \% \mathrm{Cr}, 0,05-1 \% \mathrm{~N}$, below $0,09 \%$ $\mathrm{P}$ and $\mathrm{S}$. Some of the steels and cast iron are additionally alloyed with $\mathrm{V}, \mathrm{Mo}, \mathrm{Al}, \mathrm{Pb}$ at general sum to $2,5 \%$ austenitization and quenching of $1100-1200^{\circ} \mathrm{C}$ that austenite can be strengthened with $\mathrm{N}$ and $\mathrm{C}$ separately or together with both elements. $\mathrm{N}$ increases the strength of stretching under equal other conditions with $4-6 \cdot 10^{-7} \mathrm{~Pa}$ every $0,1 \% \mathrm{~N}$. On statistical basis we obtained mathematics models which help evaluate the influence of the sum $\mathrm{ZC}+\mathrm{N}$ in the range $0,18-1,8 \%$ on the strength of stretching and the relative border of sprawling $\left(\sigma_{02}\right)$ in cast alloys containing $12-14 \% \mathrm{Mn}$, $4-6 \% \mathrm{Cr}, \quad 0,4-0,6 \% \mathrm{~V}, 0,25-0,5 \% \mathrm{Mo}, \quad 0,15-0,2 \% \mathrm{Al}$. Carbon has been changed within the range 0,09 $1,15 \%$ and $\mathrm{N}=0,08-0,9 \%$. The following regression equations have been obtained after 47-48 experiments: I. For the strength tensile $\sigma_{B}=36,66+45,28$ $(\mathrm{C}+\mathrm{N})-10,24 \%(\mathrm{C}+\mathrm{N})^{2}$; for the yield strength $\sigma_{02}=$ $17,035+50,95(\mathrm{C}+\mathrm{N})-13,97(\mathrm{C}+\mathrm{N})^{2}$. The elongation $\delta_{5}$ varies within the range $10-13 \%$ up to $30-35 \%$, impact strength (ak) from 4-6 to $17-20.10^{5} \mathrm{~Pa} \mathrm{j} / \mathrm{m}^{2}$.

The hardness varies within the range 200$300 \mathrm{HB}$. The influence of plastic characteristics higher than that of nitrogen [7, 15-17], in nitrogen, nitro-carbon austenite alloys (steels) can be reached higher plastic characteristics compared to only carbon steels. This reveals possibilities and perspectives for regulation of strength and plastic characteristics when introducing $\mathrm{C}$ and $\mathrm{N}$ in the melt separately or together in $\mathrm{EC}+\mathrm{N}$ at different ratios $\mathrm{C} / \mathrm{N}$ or $\mathrm{N} / \mathrm{C}[7,14-20]$.

We obtained high and medium-alloyed with $\mathrm{Cr}$ cast austenite steels, which after high temperature homogenization and quenching possess yield strength up to 3-4 times higher than that of classic austenite $\mathrm{Cr}-\mathrm{Ni}$ steel of the type $\mathrm{C} 10 \mathrm{Cr} / 8 \mathrm{Ni9Ti}$ and up to 1,5-2 times higher than that of the famous Hatfield steel $\mathrm{C} 110 \mathrm{MnI} 3$, patent claim RJB31141. Cast alloys of the system Fe-Cr-Mn-C(N) with austenite-carbide structure after high temperature austenitization and quenching possess high mechanic properties $\left(\sigma_{B}\right.$ reaching $80-90.10^{7}$ $\mathrm{Pa}$, hardness to $500-600 \mathrm{HB}$ ) and lower plasticity $\left(\delta_{5}\right.$ and $\mathrm{a}^{\wedge}$ depending on quantity, shape, size, distribution and type of residual carbide phase. Decreasing $\mathrm{Mn}$ quantity first come the unstable under deformation steels, then we reach martenzite (ferrite) class, at Mn content below 1-3\%.

Table 1 presents some generalized data on strength tensile $\left(\sigma_{B}\right)$, yield strength $(\sigma 0 \mathrm{I})$, elongation $\left(\delta_{5}\right)$ impact strength $\left(\mathrm{a}^{\wedge}\right)$ and hardness of $\mathrm{N}$-free and $\mathrm{N}$-containing cast austenite alloys from the different phase areas of the systems Fe-Cr-Mn-C$\mathrm{N}$ and Fe-Cr-Mn-C. The advantages of alloys in the respective phase areas $(\gamma, \gamma+k . k-$-carbide) ) are obvious-steels and cast iron, containing $\mathrm{N}$ in comparison with alloys of the same phase areas with C, without N [7, 12]-patent claim RB3 1141 and RB49451. At one and the same sum EC+N for steels of $y$-area, better strength characteristics and especially plasticity have those containing less $C$. This shows that $\mathrm{N}$ creates conditions for obtaining better plastic characteristics towards $\mathrm{C}$, and up to higher content, irrespective of the fact that both elements form solid solutions of introduction. The mechanism of influence of both elements on strength and plastic characteristics has been theoretical presented in $[7,16-17,22]$. It is determined by the similarities and differences in the influence of $C$ and $N[7,12,18]$. For example: at the sum $\Sigma \mathrm{C}+\mathrm{N}=1,5-1,6 \%$ and $4-7 \% \mathrm{Cr}, \sigma_{\mathrm{B}}$ is $1.55-$ 1,65 times better than $N$ free steels with the same sum $\Sigma \mathrm{C}+\mathrm{N}$, i.e containing I,5-I,6\% $\mathrm{C}$; $\sigma_{\mathrm{O} 2}$ is 1.35 1.5 times better and $\delta_{5}$ under the same conditions is 9-14 times better than that of alloys not containing $N$ or at $1,5-1,6 \% \mathrm{C}$. Impact strength $\left(a_{k}\right)$ under the same conditions is 3-5 times better.

The differences in hardness are minor. Hardness of high carbon steels without $N$ at $1,5-1,6 \% \mathrm{C}$ is with $45-67 \mathrm{HB}$ higher than that of $\mathrm{N}$ containing with sum $\mathrm{C}+\mathrm{N}=1,5-1,6 \%$. This means that $\mathrm{N}$ increases hardness to a smaller extent which is not equal to strengthening. Nitride phases are thermodynamically more unstable than carbide ones. Under austenization $\left(1150^{\circ} \mathrm{C}\right) \mathrm{N}$ is completely in the solid solution and $\mathrm{C}$ can remain under the form of residual carbides $[7,12,18]$.

Comparative results from table 1 show that when introducing only $C$ in the melt high as and high $\sigma_{\mathrm{O} 2}$ can be reached alike the introduction of $(\mathrm{C}+\mathrm{N})$ but at considerably lower plastic characteristics. High values of $\sigma_{02}$ in austenite alloys of the system Fe-Cr-Mn-C-N without $\mathrm{N}$ are obtained at lower $C$ content $(0,18-0,55 \% C)$ and higher $\mathrm{Cr}$ content. This is significant from economic point of view, with advantage towards $\mathrm{N}$ containing. Irrespective of the fact that $C$ increases $\sigma_{02}, \mathrm{~N}$ - containing alloys have certain advantage, having higher values in this characteristics $\left(\sigma_{02}\right)$ even at higher values of plastic characteristics $\left(\delta_{5}\right.$ and $a_{k}$ ). With one and the same composition and equal $\mathrm{C}$ and $\mathrm{N}$ content the extent of strengthening is higher in $\mathrm{N}$-containing cast austenite steels, table 1. 
Table 1 - Mechanic characteristics of wear-resistant austenite cast alloys of the Fe-Cr-Mn-C system containing 12-16\% Mn, with and without Nitrogen

\begin{tabular}{|c|c|c|c|c|c|c|c|c|c|c|c|}
\hline $\mathrm{N}$ & $\begin{array}{l}\text { Type } \\
\text { Alloy }\end{array}$ & $\begin{array}{c}\text { Phase } \\
\text { area }\end{array}$ & $C, \%$ & $\mathrm{~N}, \%$ & $\mathrm{C}+\mathrm{N}, \%$ & $\mathrm{Cr}, \%$ & $\begin{array}{c}\text { Tensile } \\
\text { strenght } \\
\sigma_{\mathrm{B}} \\
10^{-7} \mathrm{~Pa}\end{array}$ & $\begin{array}{c}\text { Yeld } \\
\text { strengt } \\
\sigma_{02} \\
10^{-7} \mathrm{~Pa}\end{array}$ & $\begin{array}{c}\text { Plasticity } \\
\text { sharply } \\
\delta_{5} \\
\%\end{array}$ & $\begin{array}{c}\text { Impact } \\
\text { strenght } \\
a_{k} \\
10^{5} \mathrm{~J} / \mathrm{m}^{2}\end{array}$ & $\begin{array}{c}\text { Hardness } \\
\text { HB }\end{array}$ \\
\hline \multirow{2}{*}{1} & \multirow{2}{*}{$\begin{array}{l}\text { Steels } \\
\text { with N }\end{array}$} & \multirow{2}{*}{ Y } & $0.80-$ & $0.70-$ & $1.50-$ & $4.00-$ & $91-93$ & $63-66$ & $35-28$ & 18-12 & $270-300$ \\
\hline & & & 0.15 & $0.74-$ & $0.89-$ & 5.00 & $72-74$ & $55-59$ & $28-18$ & $17.9-4.5$ & $236-262$ \\
\hline \multirow{2}{*}{2} & \multirow{2}{*}{$\begin{array}{l}\text { Steels } \\
\text { without }\end{array}$} & \multirow{2}{*}{ Y } & $0.90-$ & & $0.90-$ & $6.50-$ & $43-47$ & $32-39$ & $6-5$ & - & $248-268$ \\
\hline & & & $1.50-$ & & $1.50-$ & $4.00-$ & $55-60$ & 45-49 & $4-2$ & $5-3$ & $315-387$ \\
\hline \multirow{2}{*}{3} & \multirow{2}{*}{$\begin{array}{l}\text { Steels } \\
\text { with N }\end{array}$} & \multirow{2}{*}{$Y+k$} & $0.77-$ & $0.38-$ & $1.45-$ & 12.0 & $68-77$ & & $20-10$ & $4-2.5$ & - \\
\hline & & & $0.78-$ & $0.43-$ & $1.35-$ & $18.0-$ & $84-91$ & & $16-8$ & $25-1.5$ & - \\
\hline \multirow{4}{*}{4} & \multirow{4}{*}{$\begin{array}{l}\text { Steels } \\
\text { without } \\
\mathrm{N}\end{array}$} & \multirow{4}{*}{$Y+k$} & $1.00-$ & - & $1.00-$ & $120-$ & $55-62$ & $47-50$ & $6-2$ & & - \\
\hline & & & $0.90-$ & - & $0.90-$ & $18.0-$ & $55-65$ & 54-62 & $1.5-0.5$ & & $277-296$ \\
\hline & & & $1.40-$ & & $1.40-$ & $120-$ & 73-78 & $63-67$ & $2-1$ & & $362-412$ \\
\hline & & & $1.55-$ & & $1.55-$ & $18.5-$ & $65-74$ & $57-62$ & - & - & $369-415$ \\
\hline \multirow{2}{*}{5} & \multirow{2}{*}{$\begin{array}{l}\text { Casts } \\
\text { with N }\end{array}$} & \multirow{2}{*}{$Y+k$} & $240-$ & $0.30-$ & $2.70-$ & $120-$ & $65-81$ & - & $<2.5-1$ & $1.15-0.45$ & $405-500$ \\
\hline & & & $240-$ & $0.21-$ & $2.70-$ & $18.0-$ & 60-72 & - & $<2-1.5$ & $0.80-0.42$ & $415-520$ \\
\hline \multirow[b]{2}{*}{6} & \multirow{2}{*}{$\begin{array}{l}\text { Casts } \\
\text { without } \\
\mathrm{N}\end{array}$} & \multirow[b]{2}{*}{$Y+k$} & $250-$ & & $2.50-$ & $120-$ & $23-53$ & - & & & $520-598$ \\
\hline & & & $\begin{array}{l}2.40- \\
3.20\end{array}$ & - & $\begin{array}{l}2.40- \\
3.20\end{array}$ & $\begin{array}{l}18.0- \\
19.0\end{array}$ & $48-59$ & - & & & $495-593$ \\
\hline
\end{tabular}

2.2. Summarized results from studies on wear resistance and complex alloyed highstrength austenite cast alloys steels and cast iron: The basic factors determining wear resistances are phase resp. chemical composition. Various processes of wearing reflect in different ways on formation of structure, resp. on wear resistance $[7,12,18]$. According to enhanced wear resistance criterion the phases and structure components graduate as follows: ferrite, perlite, sorbite, troostite, martenzite. Austenite is contradictory evaluated because of insufficient research. Austenite of steels of the type $\mathrm{C} 10 \mathrm{Cr} / 8 \mathrm{Nil0}$ is corrosion resistant but poorly wear resistant even in conditions of wear and corrosion Austenite of steels of the Hatfield type (C110Mnl3) is highly wear resistant under strike pressure and poorly corrosion resistant and heat resistant which makes them inappropriate for work in complex conditions of wearing. The attempt to improve wear resistance of steels of type ClIOMn13 by additional alloying with carbide-forming even with stabilizing austenite elements of substitution or by diminishing the austenite stability in cold deformation conditions (strike pressure) has not given any positive results. Improvement of some properties ( $\sigma_{B}$, HB etc.) is accompanied by decreasing of other (plasticity, strike elasticity-resistance against fine destruction under strike pressure or repeated plastic deformation etc.). Obviously until recently (patent RB 31142, RB49451, RB51734 etc. [8]) scientists considered $\mathrm{C}$ (along with $\mathrm{Mn}$ ) for the only and most important element determining wear resistance of steels of the Hatfield type, resp. possibilities for strengthening and reaching of optimum combination between strengthening and plastic characteristics. Hens we should expect that strengthening of austenite under the influence of $\mathrm{C}$ and $\mathrm{N}$ should lead to improvement of wear resistance. Under interaction between abrasive particles and details surface, there is processes of surface plastic deformation, micro cutting or surface microdistmction. Similar processes take place under friction wearing.

Under strike pressure there is a surface settling which according to the extent of stability leads to strengthening and obtaining of surface deformation martenzite. Because of this the increase in strength, hardness extent of deformation strengthening and resistance towards fine destruction leads to improvement of wear resistance of $\mathrm{Cr}-\mathrm{Mn}$ austenite containing $\mathrm{C}$ and $\mathrm{N}$ separately and togheder. For testing of wear resistance we used two methods; 1) of friction-by laboratory mashine "Schoda-Savine", 2) weight method-wearing under abrasive, hidroabrasive and strike abrasive pressure, combined with certain strike pressure (Personally developed laboratory machine). Basic studies are after austenitization and quenching in water. We made an attempt to test wear resistance of alloys of both studied systems after following "aging". Summarised results of the studies on wear resistance of cast austenite alloys of 
the system Fe-Cr-Mn-C-N boildownto;[7,15, 19,20] (patents Claim RB31141, RB49451 etc. [8]

1. Increasing the content of $\mathrm{C}, \mathrm{N}, \Sigma \mathrm{C}+\mathrm{N}, \mathrm{Mn}$, $\mathrm{Cr}$ and the pressure of crystallisation, wear resistance of austenite cast alloys containing 1-8 $(12,5 \%) \%$ Cr improves. It is obtained the following regression equation for wearing $\left(\mathrm{g} / \mathrm{mm}^{3}\right)$ by" Schoda-Savine" method; $45.10^{5} \mathrm{~Pa} ; 0,6-\mathrm{I}, 2 \% \mathrm{Si} ; 1150$ ${ }^{\circ} \mathrm{C} / \mathrm{H}_{2} \mathrm{O}$ : a) $\mathrm{W}=\mathrm{f}(\mathrm{C}, \mathrm{wt} \%)=179,204 \mathrm{C}^{4}-$ $1524.604 C^{3}+4591,278 C^{2}-5865.909 C+3222,174$ $(0,15<\mathrm{C}<3,2 \%, \mathrm{~N}=0,4-0,6 \%, \mathrm{Mn}=16=18 \%, \mathrm{Cr}=6=$ $7,5 \%)$, b) $\mathrm{W}=\mathrm{f}(\mathrm{Cr}, \mathrm{N}, \quad$ wt. $\%)=-78,486 \mathrm{Cr}+$ $441.932 \mathrm{~N}+1124(0,5<\mathrm{Cr} .<12,5 \% ; 0,04<\mathrm{N}<1 \% \mathrm{~N}$, $\mathrm{Mn}=16-18 \%, \mathrm{C}=0,7-0,8 \%), \mathrm{c}) \mathrm{W}=\mathrm{f}(\mathrm{Mn}, \mathrm{N}, \mathrm{wt} \%)=$ $10,167 \mathrm{Mn}^{2}-225,65 \mathrm{Mn}+615910^{3} \mathrm{~N}^{2}-1313 \cdot 10^{3} \mathrm{~N}-$ 355,87 Mn.N + 3,889.10 3 (10<Mn < 28\%, 0,2< $\mathrm{N}<1 \%, \mathrm{C}=0,55-0,7 \%, \mathrm{Cr}=4-5 \%)$. d) $\mathrm{W}=\mathrm{f}(\mathrm{N}-\mathrm{wt} \%)=$ $999,81 \mathrm{IN}^{2}-2579 \mathrm{~N}+2255\left\{5<\mathrm{P} 10^{5} \mathrm{~Pa}<45, \mathrm{~N}=\mathrm{f}(\mathrm{P}\right.$ pressure) $=0,019 \mathrm{P}+0,0048\}$. The alloys (steels and cast iron) with austenite-carbide structure after austenization [7, 12] have better wear resistance than steels with monophase austenite structure but have worse plastic characteristics. Increasing Cr content up to $12-14 \%$ in alloys containing 16$18 \% \mathrm{Mn}, 0,7-0,8 \% \mathrm{C}$. Wear resistance is slightly improved. The slight influence of $\mathrm{Cr}, \mathrm{Mn}$ and pressure is explained with the determining action of the absorbed under their effect $\mathrm{N}$. We obtained medium and low alloyed with $\mathrm{C}$ cast austenite alloys with $\mathrm{C}+\mathrm{N}>0,8-1,2 \%$, which after austenitization and quenching possess higher yield strength and better wear resistance than the classic austenite Hatfield steel (C 110Mnl3); up to 1,5-2 times (separate parts up to 3-5 times) in alloys with austenite structure and up to 4-6 times (separate parts even more) in cast iron and many times better wear resistance than classic Crt-Ni austenite of the type ClOCrISNilO. We determined the ratios between the component at which after high temperature austenization and quenching is obtained optimum combination between mechanic characteristics and wear resistance and good corrosion rersistance(to grade 4 according to $R B$ standard BSS17043-89);

Steels with austenite structure (y-area); a) stable structure; $\mathrm{C}=1,3-0,5 \% ; \mathrm{N}=0,06-0,9 \%$, $\mathrm{Si}=0,8-\mathrm{I}, 2 \% ; \mathrm{Mn}=28-11 \% ; \mathrm{Cr}=8-2 \% ; \mathrm{S}, \mathrm{P}<0, \mathrm{I} \%$, b) unstable structure -under deformation; $\mathrm{C}=0,4$ I,2\%, $\mathrm{N}<0,2 \%, \mathrm{Cr}=0,7-1 \%, \mathrm{Mn}=6-10 \%, \mathrm{~S}, \mathrm{P}<0,1 \%$. The stable, as well as the unstable can be additionally alloyed preserving their monophase structure after austenitization and quenching, with $\mathrm{V}$ up to $0,5-1,5 \%$, Mo to $0,5-1 \%$, Al up to $0,5-$ $0,8 \%, \mathrm{~Pb}$ up to $0,4 \%, \mathrm{~W}$ to $0,3-1 \%$ etc., separately and in combination to $2-2,5 \%$.

After austenitization and quenching in water they have following mechanic characteristics;
$\sigma_{\mathrm{B}}=70-110.10^{\prime} \mathrm{Pa}, \sigma_{0,2}=50-82 \cdot 10^{7} \mathrm{~Pa}, \delta_{5}$ up to $40-$ $30 \%, a_{k}$ up to $25-20.10^{5} \mathrm{~J} / \mathrm{m}^{2}$. Improvement of wear resistance towards Hatfield steel $\mathrm{Cl}$ IOMnl3 under equal conditions:

- after austenitization. and quenching, in water at $1150^{\circ} \mathrm{C}$ up to $1,5-2,5$ times (sepate part to $3-5$ times), -after following heating and cooling down (aging) at $700^{\circ} \mathrm{C}$ - to $2-4$ times, -after cooling down at negative temperature (minus $65^{\circ} \mathrm{C}$ ) up to $1,5-2,5$ times.

Alloys with austenite - carbide structure $(\mathrm{y}+\mathrm{K}$ area) $[1,7,12,14-18,221$. Cast iron with composition: $\mathrm{C}=2,8-3,6 \% ; \mathrm{Si}=0,7-2 \%, \quad \mathrm{Mn}=10-15 \%$, $\mathrm{N}=0,04-0,5 \%, \mathrm{~S}, \mathrm{P}<0,1 \%$. For higher strike depending on certain conditions of exploitation. Mechanic characteristics after austenization and quenching at $1100-1150^{\circ} \mathrm{C} ; \sigma_{\mathrm{B}}=50-80.10 \mathrm{~Pa} ; \mathrm{a}_{\mathrm{k}}=1,4-$ $0,5.10^{5} \mathrm{~J} / \mathrm{m}^{2} ; 400-600 \mathrm{HB}$. Improvement of wear resistance tuwards $\mathrm{C} 110 \mathrm{Mnl} 3$ to $4-6$ times separate parts even more. In order to improve the mechanic characteristics and wear resistance these cast irons can be additionally alloyed with carbide and nitride - forming (Mo, V, W, Nb, Ti, $\mathrm{Zr}$ etc.), authors patent RB49451, RB31141 etc. [8] and for regulation strength and plastic characteristics can be introduced additionally stabilizators of austenite forming solid solutions of substitution; $\mathrm{Ni}, \mathrm{Cu}$ etc and $\mathrm{C}$ and $\mathrm{Si}$ content can be decreased to $1,5-2,2 \% \mathrm{C}$ and $0,4-0,9 \% \mathrm{Si}$, Patent RB 51734 [8]. Aging $\left(700^{\circ} \mathrm{C}\right)$ deteriorates and cooling down at negative temperatures (minus $65^{\circ} \mathrm{C}$ ) improves wear resistance of steels in $\mathrm{Y}$-area $[7,12]$. Low $\mathrm{Cr}$ alloyed (1-8\%) dispersion hard steels possess better wear resis-tance than medium or high $\mathrm{Cr}$ alloyed aging on the mechanism of interrupted separation [7, 21]. This is what show the general comparison between wear resistance and mechanic characteristics of austenite cast alloys of the systems Fe-Cr-Mn-C-N and Fe-Cr$\mathrm{Mn}-\mathrm{C}$ :

l. The best wear resistance after austenization and quenching in both systems show cast irons with residual austenite chromium eutectic, including carbides of the type $\mathrm{Me}_{7} \mathrm{C}_{3}$. Wear resistance of steels with monophase austenite structure after homogenisation and quenching of both systems is almost one and the same.

2. After aging the wear resistance of austenite alloys of the systems Fe-Cr-Mn-C containing $\mathrm{N}$ deteriorates and of the $\mathrm{N}$-free alloys imptoves. This is due to different characteristics of separating phase: carbides and nitrides (carbon-nitrides). Interruptedly aging alloys of both systems have poorer complex of mechanic and exploitation characteristics (wear resistance etc) in comparison with continuously aging mechanism (diffusion or non-diffusion) [7, 21, 22]. 
3. In austenizated and quenched condition $\mathrm{N}$ - containing austenite alloys possess better complex of strength plastic characteristics and wear resistance in comparison with $\mathrm{N}$-free. Plastic characteristics and yield strength in steels of $y$-area are better than those in $\mathrm{N}$-free alloys of the same area, table 1. This confirms the advantages of $\mathrm{N}$ containing austenite alloys. Nitrogen austenite alloys can be used for stronger pressurised (strike) details, casts or products obtained through plastic deformation) as well as for more effective lightening of details, machines and devices. Besides some $\mathrm{Mn}$ austenite steels low $\mathrm{Cr}$ alloyed (of the type $\mathrm{Cl} 10 \mathrm{Mnl} 3, \mathrm{Mn} 20$ etc.), $\mathrm{N}$-free alloys of the system Fe-Mn-Cr-C can be used basically for casts.

4. The advantages of $\mathrm{N}$-free alloys on austenite basis from the system containing above - equilibrium quantities $\mathrm{N}$ is that they can be obtained and founded in existing aggregates and devices in atmospheric conditions. This advantage is not big enough, especially having in mind the challenges of today and next century when there will be larger and more severe requirements towards production from ecological point of view[1-4,19-22]. The other advantages of free founded austenite alloys is that they can be strengthened and improved in wear resistance through "aging" (countinuous. aging) [21].

- Is it determined that from $\mathrm{N}$-free cast austenite alloys of the system F-Cr-Mn-C can obtained founded alloys with better wear resistance in comparison with some traditionally used in practices samples: maretenzite quenched and tempered, austenite $\mathrm{Mn}$ and $\mathrm{Cr}-\mathrm{Ni}$ steels. We obtained cast austenite alloys of that system having up to 4-9 times better wear resistance than steels C45, containing only $0,45 \% \mathrm{C}$ (quenched in oil and tempered at $450^{\circ} \mathrm{C}$ ) up to $4-5$ times better than steels C110Mnl3 (quenched) and up to 4-6 times better than that of austenite steel C45Cr20Nil2Mn2Si2. Best wear resistance in combination with good mechanic characteristics shows alloy $1,52 \% \mathrm{C}$, $12,5 \%$ Crand $15 \% \mathrm{Mn}$.

- Optimum combination between mechanic characteristics and wear resistance after austenization and quenching at $1150^{\circ} \mathrm{C}$ is obtained at following ratios between component in wt\%: a) steels: $\mathrm{C}=0,65-\mathrm{I}, 6 \% ; \mathrm{Cr}=10-20 \%, \mathrm{Mn}=14-16 \% ; \sigma_{\mathrm{B}}=$ $45-76.10^{7} \mathrm{~Pa} ; \sigma_{02}=33-65.10^{7} \mathrm{~Pa} ; \delta_{5}=8,5-1,6 \% ; a_{k}=15-$ $3,5.10^{5} \mathrm{~J} / \mathrm{m}^{2}, 260-360 \mathrm{HB}$. Improvement of wear resistance towards steel $\mathrm{C} 30(0,3 \% \mathrm{C})$ up to $2,5-4$ times (separate parts to 5 times) towards steel C45 $(0,45 \% \mathrm{C})$ up to $4-5$ times), towards C I IOMn13 - to 1,5-2,5 times (separates parts to 3 4,5 times) towards austenite steel C45Cr20Nil2Mn2Si2 - to 2-3,5 times; b) cast iron; $\mathrm{C}=2-2,6 ; \mathrm{Cr}=12-18 \% ; \mathrm{Mn}=14-16 \%$; Si below 0,3-
0,6\%; $\sigma_{B}=36-60 \cdot 10^{7} \mathrm{~Pa}, 400-600 \mathrm{HB}$. Improvement of wear resistance towards steel $\mathrm{C} 30$ up to $3-5$ times (separate parts to 9-12 times), towards steel C45-to 4-9 times towards Cl IOMn13- to 4-6 times, towards C45Cr20Nil2 Mn2Si2 -to 5-6 times.

5. Experimental results confirm the qualitative and quantitative deference's in influence of $C$ and $\mathrm{N}$ on mechanic characteristics and wear resistance $[7,22]$. On the basis of so far carried out studies we can make the prognostication that one and the same made alloy on Fe basis with approximately similar qualitative properties can be obtained at least by 3 metallurgical methods: a) only with $\mathrm{N}$-by the methods of new gas metallurgy with gaseous elements under pressure (MOMGP); b)only with C-by the ,,classic,, lets callif 'Carbon" metdllurgy, c)with sum $\Sigma \mathrm{C}+\mathrm{N}$ and different ratios $\mathrm{C} / \mathrm{N}, \mathrm{N}^{\prime} \mathrm{C}$ combening possibilities of classic and the new gas metallurgy under pressure. However, quantitative differences are expected. For example; steels of the Hatfield type ClI0Mn1 with or without alloying $(\mathrm{Cr}, \mathrm{Mo}, \mathrm{V}$, $\mathrm{W}, \mathrm{Ti}, \mathrm{Cu}, \mathrm{Ni}, \mathrm{Nb}, \mathrm{Al}$ etc.) can be obtained as follows: a)only with $N$ (without $C$ ) $-0,6-1,6 \% N$ regulation of ratios $\mathrm{Mn} / \mathrm{N}$; b) only with $\mathrm{C}$ (without $\mathrm{N})-0,7-1,5 \% \mathrm{C}$, regulation of ratios $\mathrm{Mn} / \mathrm{C}$. c) combined; sum $\Sigma \mathrm{C}+\mathrm{N}=0,6-1,6 \%$, when the sum is one of the same $\mathrm{C}+\mathrm{N}$, the $\mathrm{C}$ content can vary from $0 \%(0,0 \ldots)$ to $0,7-1,5 \%$ and $\mathrm{N}$ content - vice versa from $\mathrm{I}, 6 \%-0,6 \%$ to $0 \%(0,0 \ldots)$

Our priority, protected by 14 patents and innovations (steels and cast iron from different systems) determining $\mathrm{N}$ as an effective element for improvement of physico- mechanical properties exspesually of wear resistance of austenite alloys was confirmed on the international congress on the high -nitrogen steeels in Sweden and Finnland, Japan etc. [1-4, 8]

\section{Possibilities for obtaining new $N$ containing high strength complex alloyed wear resistant cast alloys of the systems $\mathrm{Fe}-\mathrm{Cr}-\mathrm{C}$ and $\mathrm{Fe}-\mathrm{Cr}-\mathrm{C}-\mathrm{N}$}

We studied a large number cast alloys with different ratio of components in wt $\% ; C=0,6-4,2 \%$, $\mathrm{Cr} .=4-34 \%, \mathrm{~N}=0,02-2,5 \%, \mathrm{Si}=0,2-2,5 \%, \mathrm{Mn}=0,2-$ $9, \%, \mathrm{Mo}=0,01-3 \%, \mathrm{~V}=0,001-1 \%, \mathrm{Ni}$ and/or $\mathrm{Cu}=$ $0,01-2,5 \%, \mathrm{Nb}=0,001-0,3 \%, \mathrm{~W}=0,01-1 \%, \mathrm{Ti}=0,01-$ $1 \%, \mathrm{~B}=0,001-0,3 \%$, Ce and/or $\mathrm{Mg}$ and/or $\mathrm{Zr}=0,01-$ $0,5 \%$ and the rest $\mathrm{Fe}$ : patent claim RB49451, RB26110, RB23669 [1,8]. Cast wear resistance alloys of the systems $\mathrm{Fe}-\mathrm{Cr}-\mathrm{C}$ and $\mathrm{Fe}-\mathrm{Cr}-\mathrm{C}-\mathrm{N}$ can be obtained in atmospheric conditions as well as under pressure (MOMGP) [1, 7, 23-27]. It is determined that $\mathrm{N}$ lowers critical points, decreases the quantity of ferromagnetic phases, increases the $y$-area and stabilises austenite, make grains smalle acting in one direction with the velocity of cooling during crystallisation in shape and pressure 
and slows down the diffusion process, suppresses disintegration, especially in tempering (aging), strengthening the matrix with its two basic forms (installed in the solid solution and chemically connected) i.e. increases the strength characterristics and hardness to certain optimum values depending on duration, temperature, cooling and solid phase reactions, preserves its strike elasticity and unlike $\mathrm{C}$ does not deteriorate it (in the studied values to $0,8-0,9 \% \mathrm{~N}$ ), improves possibilities for quenching and wear resistance and can substitute expensive and deficit elements austenite formers ( $\mathrm{Ni}, \mathrm{Cu}, \mathrm{Mn})$ even carbide and nitrideforming increasing hardness (quenching), V, Mo, $W$ etc.improves resistibiliry to slotting and treatibility with cutting instrument [23-27, 31]. Detailed information on wear resistance of cast alloys from these systems are presented in [31]. Aalloys have been obtained havig up to 6-10 times better wear resistance than that of Hatfielt steel $\mathrm{Cl} 10 \mathrm{Mn} 13$, under conditions of hydroabrasive impact wear resistance under frictyion. They have goog hardness penetration(above $150-2220 \mathrm{~mm}$ ) and high hardness up to 60-67 HRC [25-27,31].

\section{Possibilities for obtaining new $\mathrm{N}$-containing high strength complex - alloyed wear resistant cast alloys in other metal systems on Fe-C basis}

Experimentally proved are the possibilities for creation of new complex alloys with high mechanic characteristics and wear resistance on the basic of strong carbon and nitride-forming capabilities of vanadium; $\mathrm{V}, \mathrm{V}+\mathrm{Cr}, \mathrm{V}+\mathrm{Cr}+\mathrm{Mn}$. Alloys can be obtained in atmospheric conditions with and without $\mathrm{N}$ and higher pressure with above equilibrium quantities $\mathrm{N}$. We obtained austenite cast iron in the system $\mathrm{Fe}-\mathrm{Mn}-\mathrm{V}-(\mathrm{Cr})-\mathrm{C}-\mathrm{N}$ with invertibie structure, having comparable wear resistance and better plastic characteristics $\left(a_{k}\right)$ in comparison with studies austenite alloys of the systems Fe-Cr$\mathrm{Mn}-\mathrm{C}$ and $\mathrm{Fe}-\mathrm{Cr}-\mathrm{Mn}-\mathrm{C}-\mathrm{N}$ we obtained patent for innovation RB48283[8]. The best combination between strength and plastic characteristics and wear resistance come at following ratio components in wt\%; $\mathrm{C}=2,1-2,8 \% ; \mathrm{Si}=0,4-0,9 \% ; \mathrm{Mn}-10-22$ $\%$; V $=4-11 \%$. N=0,04-I,3\%; S, P, below 0.05-0,09\%; After austenization and quenching in water at 1130 ${ }^{\circ} \mathrm{C}-1200^{\circ} \mathrm{C}$ posses following mechanic characterristics; $\sigma_{B}=40-64.10^{-7} \mathrm{~Pa}, a_{k}---0.7-2,810^{5} \mathrm{~J} . / \mathrm{m}^{2} ; 36$ 51HRC. Improvement of wear resistance towards Hatfield steel C110Mnl3(by the method "ShkodaSavin") up to 2,7 times and in conditions of abrasive-hydroabrasive wearing moderate strike pressure up to 3-3,5 times better than that of steel C110Mnl3 and to 3-3,2 times towards quenched and tempered steel C45. Successful experiments about attempts of substitute pan of the expensive and deficit $\mathrm{V}$ for $\mathrm{Cr}$ have been carried out. After austenization and quenching in water at $1130^{\circ} \mathrm{C}$ following characterristics are obtained; $\sigma_{\mathrm{B}}=48$ 96.10 $0^{7} \mathrm{~Pa}, \quad \delta_{5}=0,8-5 \%, \quad a_{k}=0,7-2,4.10^{5} \mathrm{j} / \mathrm{m}^{2}, \quad 33-56$ HRC Improvement of wear resistance under abrasive wearing with certain strike pressures -to 3.58 times towards steel $C 110 \mathrm{Mn} 13$ and up to $3-7,3$ times towards steel C45. Invertibie structure with optimum mechanic properties and impact strength is obtained at sum $\Sigma \mathrm{Cr}+\mathrm{V}=13-17$.

Cast iron of the system Fe-Cr-C-(N) have more rude structure and big quantity of carbide mass increasing the brittleness. Under equal quantity of carbide phase in the cast iron from the systems $\mathrm{Fe}$ $\mathrm{Cr}-\mathrm{C}-(\mathrm{N})$; Fe-Cr-Mn-C-N and Fe-Mn-(Cr)-V-C-N advantages are on the side of $\mathrm{V}$ cast irons.thanks to more favourable distribution.shape and high hardness in strengthened elastic austenite matrix.

The used in practices cast $C$ ordinary non alloyed steels containing 0,15 to $0,6 \% C$ to not satisfy requirements for contemporary machine building. Because of low phisicomechanic and exploitation characteristics (wear resistance etc.).their application leads to increase in the weight of details, resp. of machines and devices and shortening of their life. The use of low alloyed with $\mathrm{Cr}$, $\mathrm{Ni}$, Mo steels containing 0,33-0,50\%C (of the type C35CrNiMo; C35CrNi; C35CrMo etc.) is not always justified from economic point of view. We carried out successful experiments for possibilities of creation of $\mathrm{N}$-containing low alloyed high strong wear resistant cast alloys of the type; C30Mn; C45Mn2; C45MnV; C35CrMn; CrC60CrMn; C60CrMn2; C70CrMo; C70CrMn15V; C70CrMn2; C70Cr2Mn2V; C100Mn2; Cl00CrMo; C120Cr2Mn; C120CrMn2M; Cl IOCrMnCuMo etc. The Mo content in the alloy is below $0,35 \%$ and $\mathrm{V}$ ntent below $0,20-0,28 \%$ and of $\mathrm{Cu}-0,25 \%$. Properties are studied after thermal treatment quenching and tempering at different temperature $[1,28]$

\section{Industrial testing and instalments of new complex alloyed cast alloys}

Results of long laboratory studies (1968-2003) show that cast alloys of investigation systems are characterised basically as high strong and wear resistant.. Thoss containing $12-14 \% \mathrm{Cr}$ possess also corrosion properties in: orne media [7, 12, 22]. 14 patents and innovations have been protected $[1,8]$. They concern new alloys outlining a wide range of the basic components; from $0,05-0,1 \%$ to $3,5-4,2 \% \mathrm{C}, 0,4$ to $28-30 \% \mathrm{Mn}$ to $30-35 \% \mathrm{Cr}$, from 0,01 to $1,3-2,1 \% \mathrm{~N}$. Additional alloying is used separately or together in different combinations with carbide and nitride forming and austenite forming. We carried out continuous semi-industrial testing industrial production and consum- 
ption of fascet casts working under abrasive wearing, somewhere in combination with $\mathrm{PH}=6$ 8 and definite strike pressure from light to strong variables: spades for fraction -trowing cameras in foundry production, casts for machines, producing ceramics and fireproof materials and details, hammers for parcellation of coal, stones, minerals etc., cast for high pressurised machines, machines working under variable pressure (links, tracks, teth for excavators), foscet casts for sectors of mining industry, cement industry etc .(claws for breakers, facing coatings, for mills, hydrocyclones, separators, grinding bodies etc). Industrial testing confirm results from laboratory research [31].

\section{Directions for application of developed complex -alloyed alloys}

All developed alloys are suitable for work in contact with following abrasives in dry and wet conditions- $\mathrm{PH}=6-8)$; soil, sand, coal stones, minerals, asphalt, cinder okaline, middling slime, agglomerate, ores, concentrates, clinker, cement, forming materials and mixtures for metallurgical and foundry productio ceramics and fireproof materials and mixtures, hidro transport, pneumotransport, inertmaterials etc. The main direction is substitution of traditionally used; cast iron type "Nihard"; "Climex alloy", austenite steels of the Hatfield type, $\mathrm{Cr}-\mathrm{Ni}$ steels and piling up in layers, martenzitequenched carbon steels etc. Steels with monophase austenite structure and most of all N-containing after homogenisation and quenching are appropriate for non-treatable with cutting instruments highly pressurised (strike, variable) fascet cast and details obtained after plastic deformation, working in conditions of wearing, erosion, cavitation, as well as for lightening of details, machines and devices. Steels and cast iron with austenite carbide structure are suitable for nontreatable with cutting instruments, casts working in conditions of abrasive, hidroabrasive, strike abrasive, combined with compression, corrosion mechanic wearing. Alloys of the system Fe-Cr-C and F$\mathrm{Cr}-\mathrm{C}-\mathrm{N}$ are rivals to austenite steels and cast iron. Being alloys with top wear resistance they are recommended for non-treatable and treatable with cutting instruments details, working in conditions of above-mentioned wearing. Their high quenching over $200 \mathrm{~mm}$ makes them appropriate for founding of thick-wall casts over $200-400 \mathrm{~mm}$ or for lightening of details. Vanadium cast iron with invertible structure - for founded and forget products working under variable pressure and wearing.

Industries consumers are mainly the sectors of: power engineering, building and constriction materials, mining metallurgy and foundry (dome and rolling production, agglomeration, coal and are mining) as well as general and special machine bulding $[1,31]$

\section{An attempt to classify wear resistant alloys. Development. Perspectives and prognostication}

If we make an attempt for a general classifycation of wear resistant alloys in the order of the decreasing of their wear resistance the following principle order would be obtained: 1.Complex alloyed wear resistant alloys (cast iron) of the systems $\mathrm{Fe}-\mathrm{Cr}-\mathrm{C}-\mathrm{N}$ and $\mathrm{Fe}-\mathrm{Cr}-\mathrm{C}$, containing from 6-10 to $30-35 \%$ Cr. 2.Austenite complex-alloyed cast iron of the systems; Fe-(Cr)-Mn-C-N and Fe(Cr)-Mn-C; 3. Cast iron with invertible structurecomplex alloyed in the systems: Fe-(Mn)-V-(Cr)$\mathrm{C}-\mathrm{N}$; Fe-(Mn)-V-(Cr)-C; 4. Martenzite white cast iron, medium alloyed of the type Nichard with and without $\mathrm{N}$; 5 . Perlite-white cast iron additionally alloyed with some elements -with and without $\mathrm{N} ; 6$. Martenzite steels with high and medium content of $\mathrm{C}$ and additionally economically alloyed with $\mathrm{Cr}$ and some other elements - with and without $\mathrm{N} ; 7$. Economically alloyed austenite steels with unstable structure of the systems steels with unstable structure of the systems Fe-Mn-(Cr)-C-N; Fe-Mn (Cr)-C; Fe-Cr-Mn-C-N.; Fe-Cr-Mn-C. 8.Fine perlite low alloyed with $\mathrm{Cr}$ and other elements (Mo, V, etc.) steels - with and without $\mathrm{N}$; 9. Austenite Mn and $\mathrm{Cr}-\mathrm{Mn}$ steels with stable structure with and without additional alloying in the systems: Fe-Mn(Cr)-C; Fe-Mn-Cr-C-N; Fe-Cr-Mn-C; Fe-Cr-Mn-CN.; Type Hatfield steels with and without N. 10. High-strong low alloyed steels - with and without $\mathrm{N}$; 11. Non-alloyed steels and cast iron-with and without $\mathrm{N}$. This classification is refined, improved and extended (with $\mathrm{N}$-alloys, etc.) version of $[1,32$, 34].

On the present stage as alternative for wear resistant materials, working in conditions of abrasive, hidroabrasive, strike abrasive, corrosion.-mechanic wearing come up the alloys of the first 3 groups The alloys of the third group because of their higher price will be used there, where their application is technologically justified (for example textile industry), high dynamic and variable pressurised details etc. The alloys of the first 2 groups are rivals as well as with the other groups and most of all with unstable (group 7) and stable (group 9) austenite steels. It is possible to expect substitution of forged details with founded from alloys (group 1) including for production of instruments,.Very promising are fine-perlite and martenzite steels from(group 8 and 6) which are alike, but probably the economic alloyed from group 8 and 10 will dominate. The Nichard (group 4) and austenite Mn steels of the Hatfield type (9group) are expected to be substituted by alloys of groups 
1 and 2, even by unstable austenite steels of group 7; N-alloying shall increase the competitiveness of all alloys from the above mentioned 11 groups. This concerns most of all austenite steels of group 9.

It is expected and presumed that metallurgical and foundry production shall manage to overcome the recession in its development at the end of the century stimulating active research and installation of new materials, technology machines and devices. The above mentioned groups of alloys (expect among themselves) will compete with other, including non-metal materials; compositional, ceramic,"rock" materials, rubber etc.

The basic criterion which will define the future development and competitive application of new materials (alloys and their derivatives) is expected to be not only technologic expediency and economic profit, but also obligatory echo-production [1-4].

Based on current investigations a new prospective has been outlined in metallurgy and related sciences as it has been forecasted in the period 1967-1975 and proved in the period 1979-1985 (87), developed and proved during the period 1988-1999 bis 2003 [1-12, 15-31]. If 4000 years before the human race unconsciously began to mix the little carbon atoms with the bigger iron ones, now at the end of $20-^{\text {st }}$ century we have got an experience consciously to govern, regulate control and make forecast concerning the little volatile nitrogen atoms mixing with the iron atoms separately or in combination with carbon and other alloying elements. New theoretical ideas for the part of the classical and new"gaz" metallurgy (of volatile elements) together with vacuum metallurgy in the solving of fundamental philosophical and concrete problems are expected [1-4]. According to the author a nitrogen metallurgy of the steels, cast irons, ferrite alloys as well as a nitrogen metal science, plastic deformation, welding will be developed beside the classical carbon metallurgy [1$4,7,22]$. Prerequisite for this are our studies, reflected above creation and development of $\mathrm{N}$ carbon or more general biogeneous material science is expected wiuch chakk operate with the biogenesis elements and their influence on structure and properties of materials, substances [I-4, 9]. As in clasic "carbon" metallurgy there is a strike to full burning of $\mathrm{C}$ for some reasons and on the other hand consciously to introduce $C$ in order to obtain low, medium and high carbon alloys: steels, cast iron and ferro alloys as well as in $\mathrm{N}$ alloying in future we expect to be outlined in its development the vacuum metallurgy. Its aim is to completely eliminate volatile-gaseous elements ( $\mathrm{N}$ etc.) in obtaining some special alloys and on the other hand development of metallurgy under pressure (on the basis of MOMGP) in order to alloy consciously with low, medium and high $\mathrm{N}$ content and obtaining of $\mathrm{N}$ steels, cast iron, ferro alloys, alloys, including $\mathrm{C}$ plus $\mathrm{N}$ such. Future belongs to vacuum metallurgy and metallurgy under pressure (MOMGP) i.e metallurgy in closed aggregate [1-4]. As a substitute for expensive and deficit elements is expected in the future to use largely $\mathrm{N}$ which means inevitable restriction and decreasing of mining activities not only from point of view economy of natural resources, raw materials (minerals) but also the very serious breach in nature balance, in ecosystems [1-4, 9]. The use of $\mathrm{N}$ as a residue product in a number of industrial productions corresponds to ecology-effective utilisation of waste products. The use of $\mathrm{N}$ to obtain new alloys with high mechanic characteristics, wear resistance and other special properties (corrosion and heat resistance, etc) will decrease the outlay of raw materials and metal with assist the lightening of machines and devices, the decrease the outlay of labour and energy. All this corresponds to the global economy, the development of out-oven metallurgy (metal foundry) which are like to be priorities and most effective branches of those strategic sectors, especially in ecoproduction [1-4].

Future development of $\mathrm{N}$ alloying is most probably determined by expected creation of polyand isothermal sections [1-4, 7, 12, 15, 21, 22] and condition diagrams as well as basic resemblance's and differences [22] about influence of $\mathrm{C}$ and $\mathrm{N}$ in studies in basic systems: Fe-N; Fe-C; $\mathrm{Fe}-\mathrm{C}-\mathrm{N}$; Fe-Me-N; Fe-Me-C; Fe-Me-C-N; Fe-Me(Me'.)-N; Fe-Me-(Me')-C; Fe-Me-(Me')-C-N; Me$\mathrm{N}$; Me-C; Me-C-N, where Me is: Cr.; Mo; Mn; V; $\mathrm{W}$; $\mathrm{Nb}$; (Ti, Al), $\mathrm{Zr}$ and other ferrite forming and nitride forming stabilising austenite elements which form solid solutions of "substitutions": $\mathrm{Ni}$, $\mathrm{Mn}, \mathrm{Cu}, \mathrm{Co},(\mathrm{Au}, \mathrm{Pt}, \mathrm{Pd}$ ) etc.;volatile (gaseous) elements towards $\mathrm{Fe} ; \mathrm{Mn} ; \mathrm{Zn} ; \mathrm{Pb}$, etc, surface active ( $\mathrm{Sb}, \mathrm{As}, \mathrm{Be}, \mathrm{S}, \mathrm{P}$ ) modifying volatile: $\mathrm{K}, \mathrm{Ca}$, $\mathrm{Mg}, \mathrm{Ce}$, rare earth metals etc.[1-4, 9, 21, 22].

\section{REFERENCES}

[1] Kolev.B.V. Novi kompleksnolegirani splavi na jeliazovaglerodna osnova. Izd. BPS (Avangard), ISBN954-9782-41-7, Sofia 2003, (2001)

[2] Kolev B.V.The place and part of Metallurgical sciences (Metal Casting) in resolving of Global (Ecolog.) problems. I-st.Intern.Foundry and Envir. symp. Proc. Ystanbul, nov.1998.

[3] Kolev.B.V.Materialoznanie I globalni problems. Izd. BPS (Avangard), ISBN 954-9782-74-3, Sofia, 2003

[4] Kolev B.V. Ecologo-technological trends - new conceptual and practical possibilities for the development of Metallurgy and Metal casting during the next 21 century. I- ${ }^{\text {St }}$ intern. Foundry and Envir. symp. Proc. Istanbul, nov.1998 
[5] Balevsky A.T., Y.D. Nikolov. Production method for castings of gas metal alloys. Inventor's certificate, N13649, Bulgaria

[6] Balevski A.T., I.D.Nikolov. Produc. equipment for casting of gas metal alloys. Inventor scertificate, N13849, Bulgaria.

[7] Kolev B.V. Vazmojnosty za polutchavane, structuroobrazuvane i svoistva na niakoi leiarski splavi na Fe-C osnova legirany $s$ azot. Dissertatcia. Inst. of metal science-BAS, Sofia, 1985 Bulgaria.

[8] Ko!ev B.V. Patents and sertificate's: RB23345; RB24883; RB34400; RB31141; RB49451, RB48283.

[9] Kolev B.V. On some theoretical problems connected with treatment of multicomponent melts of $\mathrm{Fe}-\mathrm{C}$ basis with volatile elements ( $\mathrm{N}$ etc.) $\mathrm{II}^{\text {nd }}$ inetr. conf. Mech. Eng.. Technol. Proceedings. Sofia ,1999, Vol 6, p.47. Kolev.B.V. On some problems of Heat treatment... 11-th. Intern.congr., Istanbul, 2002, p. 208

[10] Kolev B.V.,T,Trendafilov. Niakoi osobenosti na legiraneto na sivi doeftectichni tchguni $s$ azot, Mashinostroenie, Sofia 1981, N3, p. 122.

[11] Kolev B.V. Structuroobrazuvane i svoistva na sivi tchuguni obrabotvany s obiknoven i azotiran FeMn i s FeB. Nautchni trudove VTU "A.Kanchev"- t XXXI, Sofia, 2, Leiarski protcessi, Russe-88, Bulgaria, p. 52.

[12] Kolev B.V. Results from investigations on structure and properties of Iron based cast $\mathrm{N}$ steels and Forecasts. $8{ }^{\text {th }}$ intern. Metallurgy and Materials congr. Istanbul, 1995, vol.11, p. 1007.

[13] Hodremont E. Hanbuch der Sonderstahlkunde springer-Verlay-Berlin, Heidelberg, Verlo Stahleisen m.b.H.Dusseldorf, 1956.

[14] Babanov A., M..Pridantcev. Korrosionnostoikie staIli i splavai, Metallurgia. Moscow, 1971.

[15] Kolev B.V., Production of Fe-based N-alloyed cast alloys, 3-rd intern. conf. of high Nitrogen steels HNS"93, Proceedings. Kiev. Ukraine, 1993, P.610

[16] Kolev B.V. Investigation of the bass Mechanical properties of Casting alloys of the Fe-Cr-Mn-C-N system. 3-rd Intem. conf.of High Nitrogen Steels HNS-93.Proc. Kiev .Ukraine,1993, p.383.

[17] Kolev B.V. Vlianie na vagleroda i chroma varhu niakostnite mech. pokazateli na liaty austenitni splavy ot systemata Fe-Cr-Mn-C sled homogenizatzia i zakaliavane. Science conf. Advanced manifacturing technology, Russe, Bulgaria, 1995, p. 239

[18] Kolev B.V. Basic results from the production research and application of new Fe-Based Nitrogen alloys direction and development forecasts on the $21^{-{ }^{-t}}$ century. Development of Metallurgy in the Balkans of the beginning of the XXI $-{ }^{\text {st }}$ century. Reports. Varna, Bulgaria, 1996, p.231

[19] 19. Kolev B.V. Ecological production of High strength austenite cast alloys of system Fe-Cr-MnC-N. 1-st Intern. foundry Envir. symp. Proc., Ystanbul, nov. 1998.
[20] Kolev B.V. Ecological Production of New Cast Alloys using vast volatile elements (Nitrogen etc) under pressure. $1^{\text {st }}$ intern. Foundr.and Envir. symp. Proceedigs. Istanbul, nov. 1998 and Intern. Scientific and technological conf. Sevastopol, Ukraine, publish. Proceedings, Donetck, Ukraine, 1999, t.3, p.294. Kolev B.V. Possibilities for high performence utilisation of new perspective alloys for casting.l-st intern.Foundry and Environment symp. Proc.Istanbul, nov. 1998.

[21] Kolev B.V. (2001)Thermal Metastability in heating and coolling of some austenite Ferrous alloys Theoretical Foundations. Metal Phisics and Advansed Technology.A Research Journal, 109, 517-5323 Kolev. B. V. Metallofiz. Noveishie Tekhnologii. Institute imeni Kurdumova. Kiev, Ukraine, 1999, t. 21 ,N3, p. 69.

[22] Kolev B.V. (1997) New Fe-based Nitrogen and other volatile Elements alloys - general results, development, future prospects. I-St intern, congr, Median - Enginer. Technol. Proc.Sofia,4/13, 118 and Kolev. b. v. VI-th National Romanian Conf. with intern. part, septemb. 1999, Bucurest, Romania and Kolev.B.V. 3-rd intern.conf. on modification on properties of surface layers cf Nonsemiconding materials using particle beams. Sumy, Ukraine, .may 1999.

[23] Kolev B.V. Structuroobrazuvane na tchuguni ot sistemata Fe-Cr-C-N, sled krystalizatzia vav formata i sled termichna obrabotka. National conf. with intern. partisipation. Metaloznanie i ternichna obrabotka na metalite MTOM-98.Proc. Sozopol, Bulgaria, p.53.

[24] Kolev.B.V. Izsledvania varhu sructurata sled krystalizatzia vav formata i sled termichna obrabotka na laity stomany ot systemata Fe-Cr-C-N. Nat. conf., with inern, part. Metaloznanie i termichno obrabotvane na Metalite. MTOM'98. Proceedings. Sozopol, Bulgaria, p.60.

[25] Kolev B.V. Influence of Chemical composition on mechanical characteristics of casting wea resistant complex alloys of the Fc-Cr-(C) system. II intm.congr. Mech.Enginer. Tecchnol. and heat treatment2, Sofia, Bulgaria, sept, 199, p. 144 and VI-th nation. Romanian conf. with intern, particip. sept. Bucurest, 1999.

[26] Kolev B.V. Influence of temperature and holding time a quenching and tempering on some basic mechanic characteristics determining the application of casting wear-resistant complex alloys of the Fe-Cr-C-(N) system. II-rd intern, congress. Mech. Engineer. Technol. Proc. vol.6. Phisic.Metallurgy and $\mathrm{H}$. tretment, 2, Sofia, sept. 1999 p.I 11 and VIth Nat.Romanian conf. with intem. part.Bucurest sept. 1999.

[27] Kolev.B.V. (2003) Phisical-Mechanical and Opration Characteristics of some new Alloys of the F-Cr-C-N system; Journal de Physique, Eurodimat, France 110, 219-224. Kolev B.V. Investigation of hardenability of cast wear resist, complex alloyed alloys of Fe-Cr-C-(N) sust., II-nd inter, congr., Mech., Eng., Techn.,2, Sofia, sept. 1999, p. 134. 
[28] Kolev B.V. Vlianie na term. obrabotka varhu structurata i osnovnite mech. pokazateli na niakoi laity construktzionny stomany s povisheno sadarjanie na vaglerod VI-ma nautchna conf.Vishe voenno transportno utchilishte "T. Kableshkov". Dokladi, Sofia, 1995, t.II , p.220.

[29] Kolev B.V. Promishleny izpitania na otlivki ot novi (patentnozashtiteny) iznosoustoitchivi splavy; Nat. conf with intem. part. Proc. Metal casting. Lovetch, Bulgaria, 1998, p.83.

[30] Kolev B.V and all. (1981) Vazmojnosti za obemno nasishtane $c$ azot na siv tchugun ot vagrianka; Material science and technology, Sofia, Bulgaria, 10, 54-66.
[31] Kolev B.V.Studies on wear resistance of complex alloyed alloys of the systems $\mathrm{Fe}-\mathrm{Cr}-\mathrm{C}$ and $\mathrm{Fe}-\mathrm{Cr}-\mathrm{C}$ N. 10-th intem.Metallurgy and Materials Congress, Istanbul, 2000.

[32] Norman T., O. Gerhart. Giesserei vol, 46, N17, 1959

[33] Kolev.B.V., L.B.Fatchikov, M.V.Gantcheva. Korozionno povedenie na nerajdaemi beznikelovi stomani. XVIII NTK Conf. s mejd, utch. Defektoskopia - 2003, two papers. Bulgaria, Sozopol-2003, p. 185-190 and p.191

[34] Kolev.B.V. New high strength and wear Resistant alloys... Masinskelemenata I sistema IRMES, 2002. Masinski fakultet Jahorina, sept. 2002, pp. 367-372

\section{IZVOD}

\section{MOGUĆNOSTI EKOLOŠKE PROIZVODNJE NOVIH Fe-C LEGURA OTPORNIH NA HABANJE}

U radu su predstavljeni rezultati ispitivanja u periodu od 1968-2003. godine o mogućnostima dobijanja visoko legiranih legura, otpornih na habanje, na bazi Fe-C sivog liva i čelika legiranog kompleksima i kovanog gvožđa različitih struktura, a koji su prikazani u raznim publikacijama, patentima i drugim naučnim studijama. Rezultati ispitivanja su utvrdili ne samo uslove za primenu dobijenih legura u praksi, nego su skicirali tehničke i ekološke smernice za postizanje visoke čvrstoće $i$ otpornost na habanje legura sa $N$, koristeći nove tehnologije metalurgije gasa sa gasovitim $i$ isparljivim elementima pod pritiskom.

Ključne reči: nove livene legure, sivi liv, legirani čelici, liveno gvožđa legirano sa N, mehaničke karakteristike, ekologija, aplikacije, perspektive, predskazanje.

\section{Pregledni rad}

Primljeno za publikovanje: 08. 01. 2014.

Prihvaćeno za publikovanje: 26. 03. 2014. 